\title{
The Impact of Non-performing Loans on Bank Lending Behavior: Evidence from the Italian Banking Sector
}

\author{
Doriana CUCINELLI
}

\begin{abstract}
The aim of this study is to understand the bank lending behavior during financial crisis, in particular whether an increase of credit risk during this period can lead banks to reduce their lending activity. A second object is to investigate whether cooperative and commercial banks show different behaviors. The analysis is based on a sample of Italian banks (listed and no listed), an example of a country undergoing a credit crunch. The sample consists of 488 listed and unlisted Italian banks observed 2007-2013. Unlisted banks are included because they are the most numerous in the Italian banking system. Findings show a negative impact of credit risk on bank lending behavior, with regard to both credit risk measures: the nonperforming loans and the loan loss provision ratio.
\end{abstract}

Keywords: bank, non-performing loans, banks, growth of gross loans, credit risk, Italian banking system

JEL classification: G20, G21

UDC: $336.717 .061(450)$

Fellow Researcher in Financial Intermediation University of Milan Bicocca, Italy

E-mail: doriana.cucinelli@unimib.it

Copyright (C), 2015 International Ataturk Alatoo University. 


\section{Introduction}

This paper investigates the intertemporal relationship between bank lending behavior and credit risk, and asks whether the trend of credit risk has any impact on bank lending behavior.

The current financial crisis, which started in 2007, is an example of what can go wrong if the banking system does not respect the interplay of growth and risk. In this crisis, the growth in subprime mortgage lending, fueled by low interest rates, booming housing markets and credit securitization has led to unprecedented credit losses and serious consequences for the global economy. All this highlights the importance of the growth-risk nexus in bank lending (Dell'Ariccia \& Marquez 2006; Demyanyk \& van Hemert, 2009; Gorton, 2009). Before the crisis, banks were more willing to offer credit. Since the crisis, in what is known as the credit crunch, they have reduced credit to retail clients as well as firms.

This study asks whether the deterioration of banking loans during recent years has any effect on bank lending behavior. Secondly, the essay aims to understand whether commercial and cooperative banks have a different behavior during financial crisis.

Research hypotheses are the following:

1) An increase in bank credit risk in period t-1 leads banks to supply less credit;

2) This behavior differs between commercial and cooperative banks.

The paper contributes to banking and finance literature in various ways. First, most literature covers only relatively small samples of listed banks, whereas here, the sample is larger, and includes listed and unlisted banks. It also differentiates between the behavior of commercial and cooperative banks. Lastly, previous studies have investigated the relationship between the growth of credit loans and performance, or the relationship between growth of credit loans and bank risktaking, but to author's knowledge, there are no studies of the specific relationship between bank lending behavior and credit risk.

The paper is organized as follows. Section 2 provides a literature review. Section 3 describes the sample and the methodology used in the empirical analyses, the results of which are reported in Section 4. Section 5 describes the robustness check. The last section contains some conclusions.

\section{Literature review}

In recent years, non-performing loans have been widely discussed in the literature. Many authors focus on the determinants of NPL and obtain similar results (Hoggarth et al., 2005; Harr \& Noelsen, 2005; Bofondi \& Ropele, 2011; Louzis et al., 2012; Vogiazas \& Nikolaidou, 2011; Farhan et al. 2012; Klein, 2013; Messai \& Jouini, 2013, Bruno et al., 2015). It is found that there are two different categories of determinants: bank specific determinants (size, capitalization, funding level and 
efficiency) and macroeconomic determinants (GDP, inflation rate, unemployment and investment rates).

The issue was also discussed further back. In particular, Keeton and Morris (1987) studied non-performing loan determinants in the USA during the period 19791985 , and found that the crises in the agriculture and energy sectors were the main determinants of the worsening in NPL. Sinkey and Greenwalt (1991) and Gambera (2000) also studied the determinants of NPL in the USA and showed the important effects of macroeconomic variables on their trend.

The determinants of loan losses have also been studied internationally and outside the USA. Laeven and Majnoni (2003) analyzed data from 45 countries to investigate factors influencing loan loss provisioning and income smoothing by banks during the period 1988-1999. They found that banks which make too little provision in good times in the cycle and are forced to overreact in bad times. Fonseca and Gonzalez (2008) focus on a similar aspect: the determinants of income smoothing by management of loan-loss provisions in banks around the world. They find that there is less bank income smoothing when investor protection is strong, and where accounting disclosure, restrictions on bank activities, and official and private supervision are robust. On the other hand, there is more income smoothing with stronger market orientation and development of a country's financial system.

Messai and Jouini (2013) study the determinants of non-performing loans in Spanish, Italian and Greek banks, and find that problem loans increase when the unemployment rate and the real interest rate rise, and decrease when the GDP growth rate and profitability of bank's assets fall.

Before the financial crisis there was significant credit growth. This was largely thanks to the deregulation of financial markets and the development of information technologies in the banking industry (Panopoulou, 2005; Rinaldi \& Sanchis-Arellano, 2006). Since the financial crisis, the trend has been reversed and banks are now less willing to lend. This has led to an academic focus on bank lending behavior (Micco \& Panizza, 2006; Olokoyo, 2011; Djiogap \& Ngomsi, 2012; Swamy \& Sreejesh, 2012; Ladime et al., 2013). Key determinants highlighted in these studies are bank specific variables such as size and capitalization and macroeconomic variables such as GDP and monetary policy (Djiogap \& Ngomsi, 2012; Ladime et al., 2013). Keeton (1999) emphasizes the close relationship between the business cycle and loan growth; in particular that loan growth tends to be high during business expansion, while loan losses tend to be high during business contraction. Keeton (1999) also shows that faster loan growth leads to higher loan losses. This is because during a good business cycle, banks are more likely to grant loans to clients with weaker credit histories even when collaterals are low.

The intertemporal relationship between loan growth and bank risk, especially credit losses, has been studied at macroeconomic level in several strands of the literature (Keeton, 1999; Borio et al., 2002), but there is little research on cross- 
sectional differences in the relationship. There are few contributions on the relationship between non-performing loans and bank lending behavior. Lu et al. (2005), in a study based on a sample of public listed companies in China, discuss the relationship between banks' lending behavior and NPL. They show that the banking sector presents a bias in China, as banks are more likely to lend to stateowned firms, even though these can present a high credit risk.

Borio et al. (2002), in a study based on a sample of Spanish banks, highlight that during recession, problem loans increase as a result of firms' and households' financial distress. When the economy is growing, firms request more loans and can repay them more easily, but when the economy stalls, firms show greater distress and difficulty in repaying debts. Borio et al. (2002) show that in Spain, bank lending is strongly procyclical, and that in periods of expansion, banks are more likely to lend credit to firms with low credit quality. This leads to future problems and default, typically during downturns, with an estimated time lag of approximately three years.

Berrospide and Edge (2010) study how bank capital impacts on bank lending behavior measured by loan growth, and find that capital has a small effect on lending. Bridges et al. (2014) investigate the effects of a change in bank capital requirements on lending behavior. Their results suggest that changes in capital requirements affect both capital and lending. In response to an increase in capital requirements, banks gradually increase their capital ratios to restore their original buffers held above the regulatory minimum. Banks also reduce loan growth, which mostly returns to normal within 3 years.

Lastly, Tomak (2013) studies the determinants of bank lending behavior on a sample of Turkish banks, and finds a significant relationship between NPL and bank lending behavior in State owned banks and NPL show a negative impact on the growth of total loans.

There is a long history of studies on the relationship between capital requirement and bank risktaking in their asset portfolio (Furlong \& Keeley, 1989; Calem \& Rob, 1999; Gonzalez, 2005). These studies find that incentives to increase asset risk decline as capital increases. Before the financial crisis, banks had a higher risk appetite and were willing to lend at more risk. With the financial crisis, NPL started to grow rapidly, which led banks to reduce their risk taking and their lending behavior.

In literature, the most widely investigated aspect of this is the relationship between credit growth and banks' performance (Gorton, 2009; Demyanyk \& Van Hemert, 2009). The important relationship between credit growth and bank risktaking behavior has however been explored less thoroughly, with the exception of two recent contributions (Foos et al., 2010; Amador et al., 2013).

Foos et al. (2010) analyze whether loan growth affects the riskiness of individual banks. They find that loan growth has a negative impact on the risk-adjusted 
interest income, which suggests that loan growth is an important driver of the riskiness of banks.

Amador et al. (2013) underline the relationship between abnormal loan growth and banks' risk-taking behavior. They find that abnormal credit growth over a prolonged period of time leads to an increase in banks' riskiness, accompanied by a reduction in solvency and an increase in the ratio of NPL to total loans.

Several studies find that excessive credit growth can lead to the development of asset price bubbles. Borio et al. (2002) and Borio and Drehmann (2009) show that excessive credit growth is the main leading indicator of a financial crisis in a twelvemonth horizon, in cases where it appears that the flow of loans would remain high for the remainder of the year on the basis of forward-looking indicators.

Another important contribution on Italian credit growth is the paper published by the Bank of Italy in 2013. In this study, Panetta (2013) finds that the main obstacle to the growth of loans is the deterioration of the credit risk caused by the prolonged recession. In the first quarter of 2013, the annual rate of input nonperforming loans rose to $2.8 \%$ of total credit and to $4.5 \%$ for business loans. Panetta (2013) shows a positive relationship between non-performing loans and credit reduction by banks, or bank lending behavior. He underlines that uncertain economic prospects, the high default risk and the difficulty of assessing the soundness of each debtor generate adverse selection and aversion to rising risk among banks, which thus adopt policies of lending restrictions. This confirms the findings of Stringlitz and Weiss (1981).

With regard to cooperative banks, Panetta (2013) shows that cooperative bank activity expanded significantly between 1995 and 2008, and their market share increased. He also shows that in the early years of the financial crisis (2008-2009), cooperative banks gave stability to the loan supply thanks to their financial soundness and funding stability.

In the second half of 2011, cooperative bank liquidity suffered the effects of the sovereign debt crisis, and in October 2011 the net interbank position of the cooperative movement was in debt for the first time. In addition, cooperative banks are experiencing deterioration in credit quality. In 2012, the stock of non-performing loans increased by a quarter, and other impaired loans by almost a third.

There is thus almost unanimous evidence that banks' risk appetite is compromised by experiences related to loan losses. An increase in NPL is expected to lead to a reduction in banks' credit lines, hence the negative relationship between NPL and loan growth rate.

\section{Methodology}

The sample consists of 488 Italian banks, 412 cooperative and 76 commercial banks. Banks are both listed and unlisted. Data are based on annual frequency for 
2007-2013. Banks are considered if present in the sample for at least 4 of the total 7 years. In term of total assets, sample represents $75 \%$ of total Italian banking system.

We use an OLS regression and, in addition, as suggested by the Hausman test, a Fixed Effect regression. The Fixed effect model allows control for unobserved heterogeneity across banks. (Micco \& Panizza, 2006; Berrospide \& Edge, 2010; Carlson et al., 2013).

Bank specific data are obtained from the Bankscope database, and macroeconomic data from the IMF website. The dependent variable, bank behavior (BB), is measured by the growth of gross loan rate for each year, in line with Laeven and Majnoni (2003), Gambacorta and Mistrulli (2004), Curry et al. (2006), Berrospide and Edge (2010), Foos et al. (2010) and Alessi et al. (2014). The independent variables are divided in two groups: macroeconomics and banks' specific variables.

In the first group there are: the unemployment growth rate at time $t\left(U N E M P_{t}\right)$, the inflation growth rate at time $t\left(I N F_{t}\right)$ and the GDP growth rate at time $t$. Inflation, unemployment and GDP are used to control for loan demand as stated in Gambacorta and Mistrulli (2004), Fonseca and Gonzalez (2008), Djiogap and Ngomsi (2012), Tomak (2013) and Klein (2013). The inflation and GDP growth rate are expected to impact positively on the bank lending behaviour and the unemployment growth rate is expected to show a negative sign, this because when unemployment increases, people are less likely to ask credit.

Bank specific variables are: the non-performing loans over gross loans $\left(N P L_{i, t-1}\right)$ and the loan loss provision ratio $\left(\operatorname{LLP}_{\mathrm{i}, \mathrm{t}}\right)$ as measures of the credit portfolio quality. An increase in the value of the ratio means a worsening of the credit quality and this could lead banks to decrease their lending activity, so a negative sign is expected. In the case of the loans to deposit ratio at time $t-1\left(\operatorname{LTD}_{\mathrm{i}, \mathrm{t}-1}\right)$ and the growth of total customer deposits at time t-1 (DEP,$t-1)$ which are measures of banks' funding activity, for which, we expect a negative and a positive sign, respectively: the growth of deposits fuels an increase in loans, all things equal. A lower level of the ratio of loans to deposits represents a lower dependence on wholesale funding which means that the bank is less market constrained in its asset growth. The equity-to-total assets ratio at time t-1 $\left(E_{-} A_{i, t-1}\right)$ represents the key measure of bank solvency (Foos et al., 2010). Banks with a higher solvency are more willing to lend, so we expect a positive sign. Finally, the Tier 1 ratio (TIER_1 $1_{i, t-1}$ ) as measure of a bank's financial strength from a regulator's point of view. The increase in ratio is achieved by increasing capital or reducing lending (Jackson, 1999), therefore, we expect a negative sign.

Finally, only in the OLS regression, we introduce a dummy variable: the variable is equal to 1 if banks are commercial, 0 otherwise. The dummy variable helps to understand whether the bank lending behavior is different between cooperative and commercial banks. The dummy variable is not use in the Fixed Effect regression 
The Impact of Non-performing Loans on Bank Lending Behavior: Evidence from the Italian...

because it causes a problem of perfect collinearity. The level of banks' specific variables is measured at $\mathrm{t}-1$ in order to mitigate a possible endogeneity bias (Gambacorta \& Marque-Ibanes, 2011).

The fixed effect regression presents the following form:

$$
\begin{gathered}
B B_{i, t}=\alpha+\beta_{1} C R_{i, t-1}+\beta_{2} T_{I E R 1_{i, t-1}}+\beta_{3} L T C_{i, t-1}+\beta_{4} E_{-} T A_{i, t-1}+\beta_{5} D E P_{i, t-1} \\
+\beta_{6} \operatorname{UNEMP}_{t}+\beta_{7} G D P_{t}+\beta_{8} I N F_{t}+\varepsilon_{i t}
\end{gathered}
$$

The OLS regression has the following form:

$$
\begin{gathered}
B B_{i, t}=\alpha+\beta_{1} C R_{i, t-1}+\beta_{2} T I E R 1_{i, t-1}+\beta_{3} L T C_{i, t-1}+\beta_{4} E_{-} T A_{i, t-1}+\beta_{5} D E P_{i, t-1} \\
+\beta_{6} U N E M P_{t}+\beta_{7} G D P_{t}+\beta_{8} I N F_{t}+\beta_{9} D U M M Y+\varepsilon_{i t}
\end{gathered}
$$

Table 1 reports all variables used in the regression, the description, the source of data and the expected sign.

Table 1. Variables

\begin{tabular}{|l|l|l|c|}
\hline Variable & Definition & Source & Expected sign \\
\hline $\mathrm{BB}_{\mathrm{i}, \mathrm{t}}$ & Growth loans rate & Bankscope & $/$ \\
\hline $\mathrm{CR}_{\mathrm{i}, \mathrm{t}-1}$ & $\begin{array}{l}\text { Non performing loans on gross loans at time t-1 } \\
\text { Loan loss provisions on gross loans at time t-1 }\end{array}$ & Bankscope & - \\
\hline $\mathrm{GDP}_{\mathrm{t}}$ & Gross domestic product growth rate at t & IMF & + \\
\hline $\mathrm{INF}_{\mathrm{t}}$ & Inflation rate at time t & IMF & + \\
\hline $\mathrm{UNEMP}_{\mathrm{t}}$ & Unemployment growth rate at time t & IMF & - \\
\hline LTD $_{\mathrm{i}, \mathrm{t}-1}$ & $\begin{array}{l}\text { Loans to Customer deposit on total funding except } \\
\text { derivatives at time t-1 }\end{array}$ & Bankscope & + \\
\hline $\mathrm{E}_{-} \mathrm{TA}_{\mathrm{i}, \mathrm{t}-1}$ & Equity on total assets at time t-1 & Bankscope & + \\
\hline $\mathrm{TIER}_{\mathrm{i}, \mathrm{t}-1}$ & Tier 1 ratio at time t-1 & Bankscope & - \\
\hline DEP $\mathrm{i}, \mathrm{t}-1$ & Growth of customer deposits at time t-1 & Bankscope & + \\
\hline DUMMY & $\begin{array}{l}\text { Dummy variable is equal to } 1 \text { if commercial banks, } \\
\text { 0 otherwise. }\end{array}$ & Bankscoper & Relevant \\
\hline
\end{tabular}

The descriptive statistics of the variables are shown in Table 2, which shows the average, median, minimum value, maximum value, standard deviation, asymmetry and kurtosis of the variables described in Table 2.

Table 2. Descriptive Statistics

\begin{tabular}{lccccccc}
\hline Variabiles & Average & Median & Min & Max & Std. Dev & Asymmetry & Kurtosis \\
\hline BB $_{\mathrm{i}, \mathrm{t}}$ & 6.551 & 4.870 & -79.400 & 437.490 & 15.596 & 12.674 & 298.385 \\
NPL $_{\mathrm{i}, \mathrm{t}-1}$ & 8.202 & 7.024 & 0.001 & 40.668 & 5.111 & 1.344 & 2.890 \\
LLP $_{\mathrm{i}, \mathrm{t}-1}$ & 0.923 & 0.674 & -0.890 & 14.93 & 1.011 & 3.645 & 28.895 \\
LTD $_{\mathrm{i}, \mathrm{t}-1}$ & 3.818 & 1.423 & 0.046 & 158.423 & 47.078 & 24.944 & 68.077 \\
E_TA $_{\mathrm{i}, \mathrm{t}-1}$ & 10.897 & 10.147 & 1.234 & 50.455 & 4.180 & 1.577 & 7.632 \\
UNEMP $_{\mathrm{t}}$ & 8.630 & 8.408 & 6.100 & 12.210 & 1.985 & 0.571 & -0.839 \\
INF $_{\mathrm{t}}$ & 2.204 & 2.038 & 0.764 & 3.500 & 0.974 & -0.016 & -1.471 \\
GDP $_{\mathrm{t}}$ & -1.042 & -1.156 & -5.494 & 1.723 & 2.332 & -0.585 & -0.610 \\
DEP $_{\mathrm{i}, \mathrm{t}-1}$ & 7.969 & 4.533 & -79.508 & 352.964 & 67.845 & 45.758 & 234.137 \\
TIER1 $_{\mathrm{i}, \mathrm{t}-1}$ & 15.888 & 14.030 & 0.000 & 105.680 & 7.982 & 3.214 & 22.211 \\
DUMMY & 0.110 & 0.000 & 0.000 & 1.000 & 0.313 & 2.843 & 2.490 \\
\hline
\end{tabular}


Before carrying out the empirical analyses, the correlation between the independent and control variables was checked. This analysis appears to support the hypothesis that each independent variable has its own specific information value in its ability to explain bank lending behavior (Table 3 ).

\section{Table 3. Correlation Table}

\begin{tabular}{|c|c|c|c|c|c|c|c|c|c|c|c|}
\hline & $\mathrm{BB}_{\mathrm{i}, \mathrm{t}}$ & $N P L_{i, t-1}$ & $\mathrm{LTD}_{\mathrm{i}, \mathrm{t}}$ & $\mathrm{E}_{-} \mathrm{TA}_{\mathrm{i}, \mathrm{t}}$ & UNEMP $_{\mathrm{t}}$ & $\mathrm{INF}_{\mathrm{t}}$ & $\mathrm{GDP}_{\mathrm{t}}$ & $\mathrm{DEP}_{\mathrm{i}, \mathrm{t}}$ & TIER $1_{i, t}$ & DUMMY & ${L L P P_{i, t}}$ \\
\hline $\mathrm{BB}_{i, \mathrm{t}}$ & 1 & & & & & & & & & & \\
\hline$N P L_{i, t-1}$ & -0.167 & 1 & & & & & & & & & \\
\hline $\operatorname{LTD}_{\mathrm{i}, \mathrm{t}}$ & -0.009 & 0.045 & 1 & & & & & & & & \\
\hline E_TA $A_{i, t}$ & -0.012 & 0.083 & -0.051 & 1 & & & & & & & \\
\hline$U_{N E M P}$ & -0.231 & 0.366 & 0.008 & -0.131 & 1 & & & & & & \\
\hline $\mathrm{INF}_{\mathrm{t}}$ & 0.034 & -0.033 & 0.001 & -0.022 & -0.140 & 1 & & & & & \\
\hline $\mathrm{GDP}_{\mathrm{t}}$ & 0.068 & -0.043 & -0.004 & 0.011 & -0.273 & 0.290 & 1 & & & & \\
\hline $\mathrm{DEP}_{\mathrm{i}, \mathrm{t}}$ & 0.128 & 0.010 & 0.001 & -0.018 & 0.011 & -0.049 & -0.068 & 1 & & & \\
\hline TIER $1_{i, t}$ & -0.023 & 0.173 & -0.042 & 0.731 & 0.025 & -0.017 & 0.001 & -0.031 & 1 & & \\
\hline $\begin{array}{l}\text { DUMM } \\
Y\end{array}$ & 0.302 & -0.105 & 0.015 & -0.150 & 0.000 & 0.000 & -0.000 & 0.003 & -0.108 & 1 & \\
\hline $\mathrm{LLP}_{\mathrm{i}, \mathrm{t}}$ & -0.163 & 0.457 & -0.033 & -0.198 & 0.468 & -0.027 & -0.138 & -0.042 & 0.047 & 0.006 & 1 \\
\hline
\end{tabular}

The significance of the coefficients was calculated at the level of $95 \%$

\section{Results}

Table 4 shows the results of regression. Both regressions show a moderate ability to explain the variance of the dependent variable, this is in line with previous studies (La Porta et al., 2003; Cebenoyand \& Strahan, 2004; Tomak, 2013; Lin et al., 2013). Only the second OLS model (OLS(2)) highlights a low Adjusted R-squared.

Table 4. Results on bank lending behavior

\begin{tabular}{lllll}
\hline \multirow{2}{*}{ Const } & $\boldsymbol{F E}(\mathbf{1})$ & $\boldsymbol{F E}(\mathbf{2})$ & $\boldsymbol{O L S}(\mathbf{1})$ & $\boldsymbol{O L S}(\mathbf{2})$ \\
\cline { 2 - 5 } NPL & $22.496^{* * *}$ & $10.894^{* * *}$ & $22.450^{* * *}$ & 23.598 \\
LLP & $-0.216^{* *}$ & & $-0.159^{* * *}$ & \\
LTD & - & -0.610 & - & $-0.961^{*}$ \\
E_TA & 0.010 & $0.091^{* * *}$ & -0.003 & $-0.016^{* * *}$ \\
UNEMP & 0.353 & -0.067 & -0.107 & -0.188 \\
INF & $-1.614^{* * *}$ & $-1.629^{* * *}$ & $-1.848^{* * *}$ & $-1.652^{* * *}$ \\
TIER1 & 0.290 & 0.027 & 0.285 & 0.132 \\
DEP & $-0.391^{* * *}$ & $-0.330^{* * *}$ & 0.032 & 0.101 \\
GDP & $0.213^{* * *}$ & $0.467^{* * *}$ & $0.191^{* * *}$ & $0.029 *$ \\
DUMMY & $0.267^{* * *}$ & $0.484^{* * *}$ & $0.198^{* *}$ & -0.059 \\
R-squared & - & - & 0.258 & 0.826 \\
Adjusted R-squared & 0.357 & 0.493 & 0.201 & 0.046 \\
\hline
\end{tabular}

One, two or three asterisks represent the significance of the coefficients, meaning the refusal of the hypothesis of the non-significance of the coefficients, with a level of probability of $10 \%, 5 \%$ and $1 \%$ respectively.

As regards credit risk variables, results show, in all cases, a negative impact on bank lending behavior. This confirms the findings of Keeton (1999), Berrospide and Edge 
(2010), Alhassan et al. (2013) and it is in line with our expectation. Therefore, credit risk is an important determinant of the bank lending behavior, as well as showing a negative significant impact. In addition, the power of the impact is significant: the impact of non-performing loans in the Fixed Effect model is 0.21 per unit change of bank lending behavior in the next year and, in the OLS model, it is 0.16 . With regard to the loan loss provision ratio, the impact is significant only in the OLS model (in the Fixed Effect, the impact is negative but not significant). The magnitude of its impact is higher than the NPL impact and it is equal to 0.96 . This can be because the loan loss provisions at time t-1 have a strong impact on the banks' cost income and they could have an immediate effect on the lending strategy of the following year. The NPL ratio is a balance-sheet item and does not affects the bank income; thus, the impact on the bank lending behaviour may be more content.

With regard to the other variables, as expected, GDP growth rate shows a positive impact on the bank lending behavior, while unemployment rate displays a negative impact. The growth of customer deposits impact positively on the bank lending activity. Whether banks have high deposits, they are more willing to loan in the following period (Tracy, 2011), for most of the banks, deposits are the main funding sources for commercial banks' assets and under normal situation, growth of gross loans rate is expected to move in the same direction of banks' deposits.

Finally, with regard to the dummy variable, findings suggest that there is no difference between cooperative and commercial banks. Only the first hypothesis is confirmed. With regard to the relationship between credit risk and the growth rate of gross loans, findings support that banks are currently granting fewer loans in the face of an increase in the credit risk, this in particular with regard to nonperforming loans.

The second hypothesis is rejected because findings suggest that the impact of credit risk on bank lending behavior is similar both for commercial and for cooperative banks.

\section{Robustness Check}

A number of checks were made to assess the robustness of analysis. Specifically, variations on the equation were estimated in order to assess the robustness of the results in terms of the relationship between bank lending behavior.

Additional variables, comprising total customer deposit on gross loan, the total capital ratio and total assets were inserted into the regression. They presented no significant relevance for the independent variable. In addition, to test the robustness of the independent variable, we use two different credit risk measures: the non-performing loans on gross loans ratio and the loan loss provision on gross loans ratio. The first variable is a static measure of balance sheet; while the second is a dynamic measure of cost of credit risk. 
Another robustness check is the OLS regression. This yields results similar to those given by the Fixed Effect regression, including the sign of variable impacts, but a lower adjusted $\mathrm{R}$ squared. The Hausman test suggests to use the Fixed effect regression. However, results are reported in the methodology section to underline the impact of dummy variable on bank lending behavior.

Finally, as a robustness check of our fixed effect model, two different test are used: an F-statistic test to understand if all intercepts are the same and an F-statistic test to highlight an absence of a problem with the regressor. Both F-statistic tests result in a low p-value. Therefore, the null hypothesis can be rejected in both cases: the fixed effect regression is considered the best regression and the variables used are adequate to the analysis.

\section{Conclusions}

The study focuses on the relationship between non-performing loans and bank lending behavior. Since the crisis of 2007, bank lending behavior has changed significantly, and the term "credit crunch" has become widely used. The existence of this credit crunch was investigated by an examination of the growth in net loans in recent years, with the aim of finding out the reasons for the decrease in net loans from banks to families and firms.

The study focused on the impact of a key item on the balance sheet, NPL and loan loss provision. Non-performing loans have grown rapidly in recent years and have become a serious problem for banks. In some systems, 'bad' banks have been set up in order to clean up bank balance sheets.

It is important to note that the definition of NPL differs across the European banking system and the European Banking Authority, in collaboration with the European Central Bank, has recently issued a new definition of NPL in order to standardize the system. At the time of writing, however, the new standard is still to be adopted.

In the meantime, this study is based on the Italian banking sector and the results show clearly that the credit risk of previous years (measured with two different ratio) have an impact on bank lending behavior. While, findings suggest that cooperative and commercial banks do not show different behavior during financial crisis. Dummy is not significant; therefore, during financial crisis both commercial and cooperative banks reduce their lending activity in front of an increase of credit risk.

In conclusion, it appears that since the financial crisis, banks have started to take less risk as a result of the increase in credit risk. A bank, which takes fewer risks, may do so in the light of deterioration in its portfolio of past loans. Taking less risk leads banks to reduce their credit lines and thus show a slower growth rate in gross loans. 
The Impact of Non-performing Loans on Bank Lending Behavior: Evidence from the Italian...

\section{References}

Alessi, M., Di Colli S., \& Lopez, J. S. (2014). Loan Loss Porvisioning and relationship banking in Italy: practices and empirical evidence. Journal of entrepreneurial and organizational diversity, 3(1), 111-129.

Alhassan, A. L., Brobbey, F. O., \& Aamoah, M. E. (2013). Does asset quality persist on bank lending behavior? Empirical evidence from Ghana. Global Journal of Management and Business Research Finance, 13 (4), 1-8.

Amador, J. S., Gòmez-Gonzàlez, J. E., \& Pabòn, A. M. (2013). Loans Growth and banks' risk: new evidence. Borradores de economia, 763.

Berrospide, J. M., \& Edge, R. M. (2010).The effects of bank capital on lending: what do we know, and what does it mean. Financial and economics discussion series. Federal Reserve Board. Washington, D. C.

Bofondi, M., \& Ropele, T. (2011).Macroeconomic determinants of bad loans: evidence from Italian banks. Occasional Papers, 89.

Borio, C., \& Drehmann, M. (2009). Assessing the risk of banking crises - revisited. BIS Quarterly Review, pp 29-46.

Borio, C., Furfine C., \& Lowe, P. (2002).Procyclicality of the financial system and financial stability: issue and policy options. BIS Working papers 1, 1-57

Bridges, J., Gregory, D., Nielsen, M., Pezzini, S., Radia, A., \& Spaltro, M. (2014). The impact of capital requirements on bank lending. Bank of England Working paper, 486.

Bruno, E., lacovielle, G., \& Lazzini, A. (2015). On the possible tools for the prevention of nonperforming loans. A Case study of an Italian bank. Corporate Ownership and Control, 5(1), 7 19

Calem, P., \& Rob, R. (1999).The impact of capital-based regulation on bank risk taking. Journal of Financial Intermediation, 8, 317-352. http://dx.doi.org/10.1006/jfin.1999.0276

Carlson, M., Shan, H., \& Warusawitharana, M. (2013). Capital ratios and bank lending: A matched bank approach. Journal of Financial Intermediation, 22(4), 663 - 687. http://dx.doi.org/10.1016/j.jfi.2013.06.003

Cebenoyan, A. S., \& Strahan, P. E. (2004). Rik management, capital structure and lending at banks. Journal of Banking and Finance, 28, 19-43. http://dx.doi.org/10.1016/S0378-4266(02)00391-6

Curry, T. J., Fissel, G. S., \& Ramirez, C. D. (2006).The effect of bank supervision on Loan Growth. FDIC Center for financial research working paper, 2006-12.

Dell'Ariccia, G., \& Marquez, R. (2006). Lending booms and lending standards. The Journal of Finance, 61(5), 2511-2546. http://dx.doi.org/10.1111/j.1540-6261.2006.01065.x

Demyanyk, Y., \& van Hemert, O. (2009). Understanding the subprime mortgage crisis. The review of financial studies, 24(6), 1848-1880. http://dx.doi.org/10.1093/rfs/hhp033

Djiogap, C. F.,\& Ngomsi, A. (2012). Determinants of bank long term lending behavior in the Central African Economic and Monetary Community (CEMAC). Review of Economics and Finance, Article ID: 1923-7529-2012-02-107-08, 107-114.

Farhan, M., Sattar, A., Chaudhry, A. H. \& Khalil F. (2012). Economic determinants of non performing loans: perceptions of Pakistani bankers. European Journal of Business and Management, 4 (19), 87-100. 


\section{Doriana CUCINELLI}

Fonseca, A. R., \& Gonzalez F. (2008). Cross country determinants of bank income smoothing by managing loan-loss provisions. Journal of Banking and Finance, 32, 217-228. http://dx.doi.org/10.1016/j.jbankfin.2007.02.012

Foos, D., Norden L., \& Weber, M. (2010). Loan growth and riskiness of banks. Journal of banking and finance, 34, 2929-2940.

Furlong, F.T., \& Keeley, M.C. (1989), Capital regulation and bank risk-taking: A note. Journal of Banking and Finance, 13, 883-891. http://dx.doi.org/10.1016/0378-4266(89)90008-3

Gambacorta, L., \& Marquez-Ibanez, D. (2011). The bank lending channel: lessons from the crisis", Economic Policy, 135-182. http://dx.doi.org/10.1111/j.1468-0327.2011.00261.x

Gambacorta, L., \& Mistrulli, P. E. (2004). Does bank capital affect lending behavior? Journal of financial intermediation, 13, 436-457. http://dx.doi.org/10.1016/j.jfi.2004.06.001

Gambera, M. (2000). Simple Forecasts of Bank Loan Quality in the Business Cycle". Emerging Issues Series. Chicago: Federal Reserve Bank of Chicago.

Gonzalez, F. (2005). Bank regulation and risk taking incentives: An international comparison of bank risk. Journal of Banking and Finance, 29, 1153-1184. http://dx.doi.org/10.1016/j.jbankfin.2004.05.029

Gorton, G. (2009). Slapped in the Face by the Invisible Hand: Banking and the Panic of 2007. Retrieved from http://ssrn.com/abstract=1401882.

Harr, T.,\& Nielsen, M. J. (2005). The Dynamic Liquidation of Banks' Bad Loans. Corporate Ownership and Control Journal, 2(3), 79-87.

Hoggarth, G., Sorensen, S., \& Zicchino, L. (2005). Stress tests of UK banks using a VAR approach. Bank of England Working Paper, 282.

Jackson, P. (1999). Capital requirements and bank behavior: the impact of the Basel Accord. Working paper, 1.

Keeton, W. R. (1999). Does faster loan growth lead to higher loan losses. Economic reviewFederal reserve bank of Kansas City, 57-75.

Keeton, W.,\& Morris, C.S. (1987). Why do banks' loan losses differ? Economic Review, 72(3), 3-21

Klein, N., (2013), Non-performing loans in CESEE: determinants and impact on macroeconomic performance. IMF Working paper, WP/13/72.

Laeven, L., \& Majnoni, G. (2003). Loan loss provisioning and economic slowdowns: too much, too late? Journal of Financial Intermediation, 12, 178-197. http://dx.doi.org/10.1016/S1042-9573(03)00016-0

Ladime, J., Sarpong Kumankoma, E., \& Osei, K. A. (2013). Determinants of bank lending behavior in Ghana. Journal of Economics and Sustainable Development, 4(17), 42-48.

La Porta, R., Lopez de Silanes, F., \& Zamarripa G. (2003). Related Lending. The quarterly journal of economics, 231-268. http://dx.doi.org/10.1162/00335530360535199

Lin, S. L., Hwang D., Wang K. L. \& Xie Z. W. (2013). Banking capital and risk-taking adjustment under capital regulation: the role of financial freedom, concentration and governance control. International journal of management, economics and social sciences, 2(2), 99-128. http://dx.doi.org/10.2139/ssrn.2280481 
The Impact of Non-performing Loans on Bank Lending Behavior: Evidence from the Italian...

Louzis, D. P., Vouldis, A. T. and Metaxas, V. (2012). Macroeconomic and bank-specific determinants of non performing loans in Greece: a comparative study of mortgage, business and consumer loan portfolios. Journal of banking and finance, 36(4), 1012-1027.

Lu, D., Thangavelu, S. M. \& Hu, Q. (2005). Biased lending and non performing loans in China's banking sector. The Journal of development studies, 41(6), 1071-1091. http://dx.doi.org/10.1080/00220380500155361

Messai, A. S. and Jouini, F. (2013). Micro and macro determinants of non performing loans. International Journal of economics and financial issues, 3(4), 852-860.

Micco, A., \& Panizza, U .(2006). Bank ownership and lending behavior. Economics Letters, 93, 248-254. http://dx.doi.org/10.1016/j.econlet.2006.05.009

Olokoyo, F.O. (2011). Determinants of commercial banks' lending behavior in Nigeria. International journal of financial research, 2(2), 61-72. http://dx.doi.org/10.5430/ijfr.v2n2p61

Panetta, F. (2013). II Credito e il finanziamento alle imprese. Federazione delle banche di Credito Cooperativo Lazio Umbria Sardegna, Intervento del Vice Direttore Generale della Banca d'Italia. Roma, 21 giugno 2013.

Panopoulou, M. (2005). Technological Change and Corporate Strategy in the Greek Banking. Industry. Athens: Center of Planning and Economic Research. Working Paper n. 02-13.

Rinaldi, L., \& Sanchis-Arellano, A. (2006). Household Debt Sustainability: What Explains Household Non-performing Loans? An Empirical Analysis, ECB Working Paper.

Sinkey Joseph, F., \& Mary, B. G.(1991). Loan -Loss Expereince and Risk Taking Behaviour at Large Commercial Banks. Journal of Financial Services Research, 5(1), 43-49. http://dx.doi.org/10.1007/BF00127083

Stiglitz, J. E., \& Weiss, A. (1981). Credit Rationing in Markets with Imperfect Information. American Economic Review, 71(3), 393-410.

Swamy, V., \& Sreejesh, S. (2012). Financial instability, Uncertainty and banks' lending behavior. MPRA Paper, 47518. Retrieved from http://mpra.ub.uni-muenchen.de/47518/

Tracy, M., (2011). The impact of Non-performing loans on Loan Growth: an econometric case study of Jamaica and Trinidad and Tobago. Working Paper. Financial Stability Department. Bank of Jamaica.

Tomak, S. (2013). Determinats of commercial bank' lending behavior: evidence from Turkey. Asian Journal of Empirical Research, 3 (8), 933-943.

Vogiazas, S. D., \& Nokolaidou, E. (2011). Investigating the determinants of non-performing loans in the Romanian banking system: an empirical study with reference to the Greek crisis. Economics Research International, 2011, Article ID 214689. http://dx.doi.org/10.1155/2011/214689 